\title{
Blind parents and nutrition of children: experiences and care
}

\author{
Pais cegos e a nutrição dos filhos: vivências e cuidados
}

Kariane Gomes Cezario ${ }^{1}$, Paula Marciana Pinheiro de Oliveira ${ }^{2}$, Albertina Antonielly Sydney de Sousa ${ }^{1}$, Quitéria Clarice Magalhães Carvalho ${ }^{1}$,Viviane Peixoto dos Santos Pennafort ${ }^{1,3}$, Letícia Adriana Pires Ferreira dos Santos ${ }^{1,3}$

Objective: to understand the experiences of blind parents in care related to breastfeeding and complementary feeding of children. Methods: qualitative research with the participation of four blind mothers and five blind fathers. Home interviews were carried out to address the experience of feeding children in the context of blindness, categorized by the technique of thematic analysis. Results: three categories emerged: Breastfeeding and complementary feeding offered by blind mothers; Blind fathers and the feeding of children; and Care of the children and blindness: coping strategies, in which difficulties and alternatives developed to feed the children were highlighted. Conclusion: blind parents have difficulties similar to those seer parents but with specific demands associated with the handling of utensils in safe and satisfactory supply of food.

Descriptors: Child Nutrition; Blindness; Family; Nursing; Nursing Care.

Objetivo: compreender as vivências de pais cegos nos cuidados relacionados à amamentação e alimentação complementar dos filhos. Métodos: pesquisa qualitativa, com participação de quatro mães e cinco pais cegos. Realizaram-se entrevistas domiciliares sobre a experiência de alimentar crianças no contexto da cegueira, categorizadas pela técnica de análise temática. Resultados: emergiram três categorias: Amamentação e alimentação complementar ofertadas por mães cegas; Pais cegos e a alimentação dos filhos; e Cuidado dos filhos e a cegueira: estratégias de enfrentamento, em que foram ressaltadas dificuldades e alternativas desenvolvidas para alimentar os filhos. Conclusão: os pais cegos possuem dificuldades semelhantes aos pais videntes, porém com demandas específicas, associadas ao manuseio de utensílios na oferta segura e satisfatória do alimento.

Descritores: Nutrição da Criança; Cegueira; Família; Enfermagem; Cuidados de Enfermagem.

\footnotetext{
${ }^{1}$ Centro Universitário Estácio do Ceará. Fortaleza, CE, Brazil.

${ }^{2}$ Universidade da Integração da Lusofonia Afro-brasileira. Redenção, CE, Brazil.

${ }^{3}$ Universidade Estadual do Ceará. Fortaleza, CE, Brazil.
} 


\section{Introduction}

Complementary feeding is understood as the supply of food to children in addition to breast milk. Such nutrition is recommended to be introduced at the age of six months of life, when the child is in the moment of its development in which neurological and physiological maturity requires further nutrients than those present in breast milk ${ }^{(1)}$.

This period of the life cycle, which includes the first year of life, more specifically from six to 12 months, is marked by intense biological changes, including: maturity of the gastrointestinal tract, tooth eruption, disappearance of the extrusion of reflection and improvement swallowing, head control and hand-eye coordination ${ }^{(2)}$. These are developmental milestones that allow the introduction of new foods into the child's diet and make this phase of development essential to conduct interventions.

However, care related to complementary feeding of infants may constitute a real challenge as it comes to parents with some kind of disability, especially in the case of sensory impairments. The absence of vision, for example, can be an obstacle, because it requires that parents develop coping strategies for autonomous and safe care of the children, besides the need to support from the social network and health professionals.

Studies that investigated the characteristics of the care of blind mothers to their children found that most of them had difficulties in carrying out care related to feeding, hygiene and accident prevention. This happens because the sensory impairment causes the realization of such care in a proper and safe way to become very precarious. In addition, they used the social support network as a major source of guidance and assistance in situations that required the use of vision, such as identifying whether a child was sick and administering medications to the children ${ }^{(3-5)}$.

However, it is observed the literature the components of the social support network, who are represented by parents, siblings, neighbors and health professionals, very often have difficulties in providing information about the health care of children. This happens due to the lack of experience of transmitting guidelines for disabled people, or by the fact that the information provided does not take the characteristics peculiar to blind people into account, which are necessary for the proper performance of their activities, such as encouraging the use of touch, smell, and the need for adequate spatial orientation of objects $^{(6-7)}$.

In a wider context of assistance, the child nursing care in public or private systems should include diverse practices such as health surveillance, work process organization and encouraging care to strengthen the ties between family and child, prioritizing health promotion.

In the context of specific assistance, the need for nurses to assess the demands of parents with disabilities is highly important in order to adjust them to the children's development processes, guiding them effectively. However, before the development of strategies, it is necessary to identify the specific needs of these parents to build appropriate interventions to their needs.

In this context of specific care, it is essential that nurses have different training, based on the sensitivity and humanization, so as to embrace the subjective aspects of the care relationship between disabled parents and their children. Thus, these professionals can be an important source of social support from the understanding of the experiences of those subjects and intervention on their needs.

Given the above, this study aimed to understand the experiences of blind parents in care related to breastfeeding and complementary feeding of children.

\section{Methods}

This is a qualitative research conducted with blind women and men coming from and living in the city of Fortaleza, Brazil. Due to the lack of official information on the number of blind people in this city 
and also the lack of information on how many blind people had children, these people were contacted by indication of their peers, from the experience of dealing with a State association for blind people. Thus, the sample was formed through snowball method. From this approach, data were collected in the homes of families in February 2012, through interviews previously appointment by telephone.

Participants of the study were four women and five men who met the sole criterion for inclusion set out in the study which was that the participants had children, natural or adopted, and that were indicated by their peers for their proximity related with the experience to be shared. There were no exclusion criteria.

A semi-structured interview was used as data collection instrument with the guiding question: "Describe how was the experience of feeding your child", in order to identify the experiences of breastfeeding and the preparation and provision of complementary foods, according to the perception of blind men and women. The interviews lasted twenty minutes in average and were conducted individually and recorded with the consent of participants. In both cases, the interviews were conducted with the couple, together, but their experiences were collected individually.

The interviews were transcribed and analyzed according to the thematic analysis technique ${ }^{(8)}$ composed by the steps: (1) pre-analysis, floating reading, constitution of the corpus and formulation of hypotheses and objectives; (2) material exploration and treatment of results and (3) interpretation. From the data analysis, emerged as categories: Breastfeeding and complementary feeding offered by blind mothers; Blind fathers and the feeding of children; and Care of the children and blindness: coping strategies, which were discussed according to literature specific of this theme.

To protect the anonymity of participants, they were identified by "mother" or "father" followed by numbering as the order of interviews (mother 1 , mother 2, mother 3, etc.). The study complied with the formal requirements contained in the national and international regulatory standards for research involving human beings.

\section{Results}

Nine blind parents participated in the study, five men and four women. Among the causes of blindness, four were acquired and five were congenital. The age of participants ranged between 21 and 40 years; the age of the children ranged from eight months to four years, with an average of three and a half. The following characteristics prevailed among parents: married status and consensual union; high school as education; and family income ranging from $\mathrm{R} \$ 800.00$ and $\mathrm{R} \$ 3,700.00$. Respondents were from Fortaleza, Brazil. Regarding the occupation of mothers, these included: proofreader of Braille, housewife, telephone attendant and community health agent; among fathers, were identified: telephone attendant, public servant, community health agent and two massage therapists.

The fact that interviews were conducted in households apparently provided participants with greater comfort and familiarity to resume past and/ or current experiences in this environment. Another aspect to consider is that all parents had children begotten by with blind people, but all children were seers, which makes the experience innovative and enriching.

\section{Breastfeeding and complementary feeding offered by blind mothers}

The first thematic category refers to reports of blind mothers in situations experienced with the first child. In this category, we saw the emergence of two sub-categories: (1) breastfeeding experience by blind mothers and (2) the perception of blind mothers about the need for the introduction of food.

Regarding the first category, the mothers 
mentioned insecurity as general care practices with the baby and, in all cases, they reported that early cessation of breastfeeding occurred. The maximum duration of breastfeeding by mothers was about four months in only two cases; in other cases, the interruption of breastfeeding occurred in the first month of life. The reason given by mothers for early weaning was associated with lower milk production, breast engorgement, lack of nipple preparation in prenatal and stress coming from coping with the maternal role.

These factors can be identified in the statements: Being first-time mother I did not have much instruction. And she had a hard time sucking and I had trouble, little milk, I had no beak, and she had reflux (Mother 1); In my first child, I had a lot of trouble, you think you have no milk, because we want a lot coming out, and we sometimes think it's little for us, but for the child that is the right amount (Mother 4).

Associated with early weaning, mothers described the introduction of complementary feeding practices in order to deal with the interruption of breastfeeding, which is related to the second subcategory identified in this thematic class. Although breastfeeding had been stopped early, the introduction of new food was improper, both early and late. There were reports of introducing soups to a three-monthaged child, and fruit to six-month-aged children weaned since the first month of life: Up to four months she used to drink only milk [artificial], within six months we started to eat fruits (Mother 1). I cannot say that she sucked. She started having soup and fruit puree [at three months of age] (Mother 2).

\section{Blind fathers and the feeding of children}

The blind men showed themselves as significant links of care to children. Although they were not direct participants in the process of breastfeeding, fathers reported providing psychological support to the mothers of their children, facilitating the process of breastfeeding by positioning the child and assisting in the management of problems with the puerperal breast, besides promoting the socialization of the previous experience as fathers.

In this thematic class, it was also possible to identify two sub-categories: (1) the support provided by blind fathers to lactating mothers and (2) the involvement of blind fathers in complementary feeding.

As for the first sub-category, the analysis revealed that blind men took care of mother and child by providing different types of support (informational and physical) and reinforced the practice of maternal care in the context of breastfeeding (appreciative support). She was afraid to exchanging a blouse, fear of suffocating the baby, I participated a lot with the psychological part, I gave support in the sense of passing my previous experience (Father 1). I helped her to get up. As I took the baby in the crib, often when she was breastfeeding, I encouraged weaning with that gadget (Parent 2). She was not able to breastfeed ... I told her to wash, pass a wet, warm washcloth. I (had) the knowledge of my parents and grandparents. Then she did this, I asked her to give a massage with the thumb and forefinger, with the warm water, and since then, she could breastfeed and the baby slept all night long (Father 4).

Considering the involvement of blind parents with complementary feeding of their children, the participation in food preparation in addition to offering the child was mentioned. They stressed, in their daily practice, the benefits of continued breastfeeding and supply of child nutrition. The need for feeding their children woke up and revealed some practices that meet best practices for infant feeding, and sometimes against them, as well as involving the act of feeding fun practice. I always stressed that it was very important [Breastfeeding] I always heard that, up to six months of life, the child should not need anything (Father 1). We make soup for two days, three ... Now what I do is to heat it in the microwave, and the porridge I do, I make juice for him (Parent 2). I used to sit with him on my lap, sometimes sat with him on the floor playing, so that he was encouraged to eat (Father 3). I would put the soother in his mouth with his finger on the nozzle close to the lid and was turning slowly and he was sucking ...Then I would take it out a little bit, let him "breathe", then picked up again and would put in his mouth, I would give like this, to sense, for not putting it in the boy's eye (laughs) (Father 5). 


\section{Care of children and blindness: coping strategies}

The experience of sensory impairment linked to maternity/paternity raised among respondents different coping mechanisms for the limitations associated with the condition of each individual. There is recurrent mention of situations of unpreparedness and even exclusion from the social support network. In addition, they emphasized the limitations recognized by the mother/father with disabilities. I needed someone's help to hold her sometimes because I was afraid of her (Mother 1). I had more difficulty in giving it (a teaspoon) to her because people who can see, can give it with one hand, but I need two hands. I will not say that it is not good, but it's different (Mother 4). I had a hard time giving the spoon, so much that I really gave up. All food that had to be given with the spoon, it was my sister who would give the baby (Mother 2). People who cannot see suffer much prejudice of people of the staff, so I let staff leave and the next day I already bathed her, in the second day of life (Father 4). The staff believes strongly that it is the family that will care for the child, never blind mother (Mother 4).

Despite the difficulties faced, blind parents have developed mechanisms to offer care and food preparation, as well as to prevent domestic accidents. The strategies explored the remaining senses, especially touch and sensitivity to understand the demands of the child without using vision. We would hold his face and put it in his mouth (the spoon) and with time he was already waiting with open mouth (Father 3). We often leave food in their face, right, she was angry with me because I was going to give food and I would leave her all dirty ... Then she would say I do not want food with Dad, no (laughs) (Father 4). I bought a bottle, she has a 'big mouth', then I put my finger, but I wash my hand ... And I put my finger up to when I reach the water. And the ' $m l$ ' are embossed ... So I have the right idea! (Mother 3). I would put the chair, pick up the spoon, put in his little mouth and keep making him suck, because then if he sucked I would be sure what he was swallowing, I would only take it off when I felt that there was nothing left, like this (Mother 4).

\section{Discussion}

Despite the specificities, blind parents have, in general, similar difficulties to seer parents in child care, but with specific demands relating to the absence of vision.

A study carried out with blind mothers found that care related to the adequacy of home environment to prevent household accidents, school monitoring, and health promotion by health care and immunization, child care and clinical care, are priorities in child care ${ }^{(9)}$.

Furthermore, the results of this study indicate, according to the reports of respondents, that the difficulties involved in the breastfeeding process and complementary feeding are also relevant in their daily routine, demanding coping of various kinds. In this context, the difficulties of blind mothers in the continuation of breastfeeding, culminating in early interruption, related to the perception of insufficient production of breast milk, breast engorgement, inappropriate nipple for feeding and stress related to the maternal role, which can also be observed among seer mothers.

Mothers who weaned early justified this fact with economic reasons, maternal employment, negative experiences in previous breastfeeding and problems in puerperal breast, with special emphasis on pain associated with breast engorgement and cracked breast $^{(10)}$. Puerperal mothers from Cariri, a municipality in Ceará, reported an that the interruption is associated with the nipple unpreparedness for breastfeeding ${ }^{(11)}$. Another relevant factor among this group was the fact that they were primiparous, coinciding with three of the four blind mothers in this study.

It is clear, therefore, multiparity is a protective factor for preventing early weaning, as there is an association between successful experience of previous breastfeeding and maintaining the current lactation. Moreover, in a systematic review of nursing actions related to early weaning in Brazil, single marital status, reflecting on domestic workload of the mother, were identified as risk factors, additional to low family income, which culminates in less access to health care mechanisms. Taken together, these factors 
favor weaning due to the difficulty of the management of the complications that happen in this process ${ }^{(12)}$.

The four blind mothers in the present study had the risk factors for weaning cited in the abovementioned studies. Only one of them was not primiparous and, even so, reported negative experiences on breastfeeding her first child, showing that there is also a bias among these mothers regarding the number of children: previous experiences may be positive or negative, a risk factor or a protective factor, to be defined by individual experience. The socioeconomic status of participants also represented a protective factor, as these mothers completed high school and lived with at least one minimum wage. Nevertheless, early weaning was not avoided.

The early introduction of complementary feeding culminates as a result of the interruption of breastfeeding. However, the reports point to inadequate feeding practices. A study developed in São Bernardo do Campo, a city of medium size in southeastern Brazil, with mothers of 1,176 infants mentions the early use of food. According to the findings, about one third of children received juices and one fourth received porridge, fruit or soup before six months of age ${ }^{(13)}$.

Another study with infants of 160 North American mothers recruited for evaluation of an intervention related to the introduction of complementary foods, $25.0 \%$ did not receive exclusive breastfeeding with three weeks of life and $49.0 \%$ did not receive it with 16 weeks ${ }^{(14)}$.

As it can be seen, mothers are the ones who mainly offer food for infants and often do this at an early age. This practice, although socially rejected, ends up being the reality of many families in which weaning occurred in the first weeks of life. Thus, newborns and infants never receive exclusive breastfeeding, not even by replacement ${ }^{(1)}$.

Although blind parents participating in this study expressed themselves as the providers of care for the babies, mistakes in the introduction of complementary foods and the interruption of exclusive breastfeeding until six months of life have become culturally constant also among this population. Once inside these cultural realities, blind parents end up being influenced and also adopt such inadvisable practices. It is clear, therefore, that parents' behavior in feeding their children is often encouraging to good eating habits, but in many ways, is influencing the early introduction of complementary foods and early weaning $^{(15-16)}$.

A study with 158 mothers with children under three years of age in El Salvador showed that many women are willing to give other foods to the baby before six months of age because the child needs and wants. Furthermore, according to most of mothers, proper nutrition is the one that has thick consistency ${ }^{(16)}$.

As we observed, the behavior of parents here exposed were directly related to the introduction of complementary feeding and was strongly associated with early diet with other foods. The behavior of parents is essential in appropriate feeding practices and health professionals should consider this and know how to handle the difficulties in favoring proper promotion of child health ${ }^{(1)}$.

The increased emphasis on these aspects refers to the fact that blind parents constantly demand the aid of their social support network to help in the situations of child care, as the resoluteness of their own actions is limited by their own disability. Emphasizing the importance of the family in this context of challenges points to a desire for autonomy and even to maternal/paternal self-efficacy in the health care of their children.

Parents feel usually anxious about supplying new foods to their infant children, especially when they are first-time parents. There is a tendency these men and women to seek information on this subject not only in the social support network, but also in books and virtual media. Therefore, showing which of these means are more reliable and can be further explored is attributed as one of the responsibilities of health professionals ${ }^{(17)}$, with emphasis for the use of 
haptic technologies involving reading in Braille and perceptions of different textures, for example.

A phenomenological study with seventeen Irish mothers with different types of special needs (visual, intellectual, spina bifida, multiple sclerosis, etc.) generated unexpected reports. An example is the fact that, for many of the health professionals who detected the pregnancies of these women, this situation was seen as shocking as they consider these women unable to take care of their children. Thus, they proposed, in two cases, the abortion of babies. There were also reports of mothers referring the unpreparedness of the nurses that assisted them, and the feeling of loneliness during the postpartum ${ }^{(4)}$. These studies corroborate our findings. However, it was revealed that, despite the lack of professional support, the parents were able to develop parenting in the context of their visual impairment.

The reports commonly identified in these studies call attention, as mentioned, for ongoing assessment of the self-efficacy of these parents in the independent care of their children. Understood as the belief of an individual on his own ability to perform certain actions and the possible influence of these on their lives ${ }^{(18)}$, self-efficacy has a role in the context of health promotion because it includes the resilience of individuals before the obstacles they have to face. This situation is a constant aspect in the lives of disabled parents.

Thus, regardless the paternal and/or maternal disability, the family has relevance in child care. This process becomes even more effective when there is stimulation of the caring skills of parents, who also have to undergo several adjustments in their roles at the varied demands of life $\mathrm{e}^{(2,5)}$.

However, the study had limitations such as an approach restricted to nutritional care of children and the short period of coexistence with the blind parents. Further research about child care, school routine and other socio-cultural aspects of the family, which demand more approximation with subjects, are recommended. Thus, the deepening of the understanding of the context of life of these families will possibly unveil other issues and habits of blind parents in the everyday care of their children, considered important contributions to planning of nursing actions.

\section{Conclusion}

The study identified the experiences of blind parents in the nutrition of their children. In this context, early weaning was a difficulty reported by many participants and was associated with previous personal experiences and myths that still surround the breastfeeding process. As the seers, blind people require health information and professional support and social support network for effective breastfeeding. It is evident, too, an insecurity reported in care practices with the children and, in all cases, the early introduction of foods unsuitable for the child's age.

Blind fathers stood out in the performance of their role as a supporters, encouragers and caregivers in the feeding process of children. These men gave the most damning reports of coping strategies, by developing caring mechanisms for the supply and preparation of food, in addition to the prevention of domestic accidents. Parents used more finely the remaining senses, especially touch and sensitivity, to understand the child's needs without using the sense of sight.

\section{Collaborations}

Cezario KG, Oliveira PMP and Sousa AAS contributed to the conception and design of the project or analysis and interpretation of data. Carvalho QCM, Pennafort VPS and Santos LAPF contributed in the writing of the article, relevant critical review of the intellectual content and final approval of the version to be published. 


\section{References}

1. Ministério da Saúde (BR). Saúde da criança: acompanhamento do crescimento e desenvolvimento infantil. Brasília: Ministério da Saúde; 2012.

2. Hockenberry MJ, Winkelstein W. Wong Fundamentos de Enfermagem Pediátrica. Rio de Janeiro: Elsevier; 2014.

3. Oliveira MG, Carvalho AT, Pagliuca LMF, Pinheiro AKB, Bezerra CP, Machado MMT. Attention model for chronic conditions: blind women and their sons. Health. 2015; 7(6):747-53.

4. Walsh-Gallagher D, Sinclair M, Mc Conkey R. The ambiguity of disabled women's experiences of pregnancy, childbirth and motherhood: a phenomenological understanding. Midwifery. 2012; 28(2):156-62.

5. Pagliuca LMF, Baptista RS, França ISX, Moreira RVO. Blind woman pregnant and ethical conflicts: a case study. Int J Human Social Scienc. 2012; 2(22):171-8.

6. Monteiro ARM, Martins MGQ, Lobo AS, Freitas PCA, Barros KM, Tavares SFV. Systematization of nursing care to children and adolescents in psychological distress. Rev Pesqui Cuid Fundam (Online) [Internet]. 2015 [cited 2016 July 13]; 7(4):3185-96. Available from: http://www. seer.unirio.br/index.php/cuidadofundamental/ article/view/3500/pdf_1691

7. Simonasse MF, Moraes JRMM. Children with special health care needs: impact on familiar daily routine. Rev Pesqui Cuid Fundam (Online) [Internet]. 2015 [cited 2016 July 13]; 7(3):2902-9. Available from: http://www.seer.unirio.br/index. php/cuidadofundamental/article/view/3577/ pdf_1644

8. Minayo MCS. O desafio do conhecimento pesquisa qualitativa em saúde. São Paulo: Hucitec; 2014.

9. Jorge HMF, Bezerra JF, Oriá MOB, Brasil CCP, Araujo MAL, Silva RM. The ways in which blind mothers cope with taking care of their children under 12 years old. Texto Contexto Enferm. 2014; 23(4):1013-21.
10. Abreu FCP, Fabbro MRC, Wernet M. Factors that intervene in exclusive breastfeeding: an integrative review. Rev Rene. 2013; 14(3):610-9.

11. Quirino LS, Oliveira JD, Figueiredo MFER, Quirino GS. Significado da experiência de não amamentar relacionado às intercorrências mamárias. Cogitare Enferm. 2011; 16(4):628-33.

12. Rivemales MC, Azevedo ACC, Bastos PL, Revisão sistemática da produção científica da enfermagem sobre o desmame precoce. Rev Enferm UERJ. 2010; 18(1):132-7.

13. Silva LMP, Venâncio SI, Marchioni DML. Práticas de alimentação complementar no primeiro ano de vida e fatores associados. Rev Nutr. 2010; 23(6):983-92.

14. Paul IM, Savage JS, Anzman SL, Beiler JS, Marini ME, Stokes JL et al. Preventing obesity during infancy: a pilot study. Obesity. 2011; 19(2):35361.

15. Avery AB, Magnus JH. Expectant father's and mother's perceptions of breastfeeding and formula feeding: a focus group study in three US cities. J Hum Lact. 2011; 27(2):47-54.

16. Atero RG, Jacobo MP, Salinas MQ. Conocimientos, actitudes y percepciones de madres sobre la alimentación de niños menores de 3 anõs en una comunidad de Lima. An Fac Med. 2010; 71(3):17983.

17. Allcutt C, Sweeney MS. An exploration of knowledge, attitudes and advice given by health professionals to parents in Ireland about the introduction of solid foods, a pilot study. BMC Public Health [Internet]. 2010 [cited 2016 July 13]; 201(10):1-8. Available from: http://bmcpublichealth.biomedcentral.com/ articles/10.1186/1471-2458-10-201

18. Uchoa JL, Rodrigues A, Joventino ES, Almeida PC, Oriá MOB, Ximenes LB. Autoeficácia em amamentar de mulheres no pré-natal e no pósparto: estudo longitudinal. Rev Enferm UFSM. 2016; 6(1):10-20. 